\title{
Methodology for preliminary assessment of the radioactivity in natural waters
}

\section{Metodologija preliminarne ocene radioaktivnosti naravnih vod}

\author{
Muzafarov Amrillo Mustafaevich*, Sattarov Gayvillo Sattorovich \\ Navoi State Mining Institute, 27-a, Yujnaya Street, Code-ZIP: 210100 Navoi City, Uzbekistan \\ *Mustofoyev.dilshod@mail.ru.
}

\begin{abstract}
This article presents the results of a preliminary assessment of the radioactivity of natural waters and the isotope analysis of drinking water. It describes the methods for the radiochemical preparation of water samples, which include concentration of uranium isotopes from water samples, extraction from impeding radionuclides and preparation of electrically countable samples. The results of violation of radioactive equilibrium between the isotopes ${ }^{234} \mathrm{U} /{ }^{238} \mathrm{U}$ and the several factors affecting this process in water samples have been obtained. It is clear from the obtained result that ${ }^{234} \mathrm{U}$ isotope concentration in groundwater is higher than that in surface water.
\end{abstract}

Key words: natural water, isotope analysis, radiochemical preparation, concentration of uranium isotopes, extraction, countable sample, violation of radioactive equilibrium, isotope concentration

\section{Povzetek}

$\mathrm{V}$ članku so opisani rezultati preliminarne ocene radioaktivnosti naravnih vod in izotopske analize pitne vode. Obravnavane so metode radiokemijske priprave vzorcev vode vključno s koncentriranjem uranovih izotopov iz vzorcev vode, njihovo ekstrakcijo izmed motečih radioaktivnih nuklidov in metode priprave vzorca, primernega za električno štetje. Rezultati vključujejo porušenje radioaktivnega ravnotežja med izotopoma ${ }^{234} \mathrm{U} /{ }^{238} \mathrm{U}$ in upoštevajo vrsto dejavnikov, ki vplivajo na ta process v vzorcih vode. Dobljeni rezultati nakazujejo, da je koncentracija izotopa ${ }^{234} \mathrm{U} v$ podtalnici višja kakor v površinskih vodah.

Ključne besede: naravna voda, izotopska analiza, radiokemijska priprava, koncentracija uranovih izotopov, ekstrakcija, analizni vzorec, porušenje radioaktivnega ravnotežja, koncentracija izotopov 


\section{Introduction}

Providing the population with high-quality drinking water conforming to the required radiation standards is a vital task of any society. This task becomes even more important in arid conditions, wherein due to the lack of drinking water, any natural water can be used in everyday life as drinking water.

In order to assess the suitability of natural water for drinking purposes, there is a necessity to conduct preliminary evaluation of the radioactivity in natural waters. This approach involves the determination of the total alpha-beta activity, isotope analysis of alpha-emitting radionuclides and, if necessary, defining the required level of intervention for water samples. Alpha spectrometry is the most affordable of the available methods for analysing alpha-emitting radionuclides. Accordingly, developing a method for the preliminary evaluation of the radioactivity of natural waters is an urgent task facing the practitioners of applied nuclear physics and radioecology $[1-4,8]$.

\section{Appliances and methods of the experiment}

Preliminary assessment of the permissibility of using water for drinking purposes can be given as the specific total of the alpha $\left(\mathrm{A}_{\alpha}\right)$ and beta $\left(A_{\beta}\right)$ activities, which must not exceed 0.2 and $2.0 \mathrm{~Bq} / \mathrm{kg}$, respectively.

In order to make a complete assessment of the drinking water to ensure that it satisfies these requirements, our study aimed to determine the specific total alpha-beta activity, evaluate the isotopic composition of the natural radionuclides and test them according to the requirement of the level of interventions [5-7]. The sequence of determination of specific total alpha-beta activity includes the following: the water sample is thoroughly mixed, and $1.0 \mathrm{~L}$ is measured and placed in a heat-resistant glass container. The glass container is set on an electric hotplate and evaporated at a temperature of not $>90^{\circ} \mathrm{C}$ on a sand bath, adding $5 \mathrm{~mL}$ of concentrated $\mathrm{HNO}_{3}$. After evaporation to a volume of $100-150 \mathrm{~mL}$, a pre-weighed porcelain cup is set on the hotplate and filled with the sample up to two-thirds of the volume, and evaporation is continued. After evaporation, the solution is poured out of the glass into the cup. The walls of the cup are washed with $20-30 \mathrm{~mL}$ of hydrochloric acid (1 M, hot) and added to the cup with the main solution. The solution in the cup is evaporated to $50 \mathrm{~mL}$, and after it cools down, $0.5 \mathrm{~mL}$ of sulphuric acid is carefully added into the cup, and then the cup is set on the hotplate to evaporate until complete distillation of sulphuric acid.

The dry residue is transferred into a muffle furnace and calcinated for 1 hour at a temperature of $350^{\circ} \mathrm{C}$, and thereafter, the sample is allowed to cool. The cup with the dried residue is weighed. The dry residues are carefully removed from the walls of the cup with a spatula, and then the precipitate is ground with a porcelain pestle to a homogeneous powder. An aliquot of the precipitate $(0.1 \mathrm{~g})$ is placed onto a special substrate, wetted with ethanol and gently spread over the entire surface. Ethanol is then fully evaporated by placing on the hotplate.

The total alpha-beta activity of the dry residue is measured using a UMP-2000 radiometer. The measurement of radioactivity for the control is carried out initially. In order to do this, empty substrate is wiped with alcohol and loaded into the counting position on the radiometer. Five measurements are conducted with the exposition of 3600. Then, this substrate is loaded with pre-staged dry residue. The measurements are conducted in the same way as the measurement of radioactivity. The radioactivity results of the control and the sample are logged in the register.

The threshold of determination is $0.01 \mathrm{~Bq} / \mathrm{L}$ for alpha-emitters and $0.1 \mathrm{~Bq} / \mathrm{L}$ for beta-emitters in drinking water.

To determine the isotopic composition of natural radionuclides in natural water, we took a $1000 \mathrm{~mL}$ sample of filtered water, which was evaporated in a porcelain cup until constant weight.

The evaporation was conducted in a distilled water bath. Then, the cup with dry residue was placed in a thermostat at a temperature of $110^{\circ} \mathrm{C}$ and dried until constant weight.

Isotopic analysis of natural waters was carried out in the following sequence. 


\section{Concentration of uranium isotopes}

The investigated water sample with volume of $1 \mathrm{~L}$ was acidified with hydrochloric acid to $\mathrm{pH}=1$ and kept for at least 6 hours. Then, the sample was heated under a watch glass for 20 minutes until the carbon dioxide is removed (if the water was coloured, before boiling, we added additional $1 \mathrm{~mL} \mathrm{H}_{2} \mathrm{O}_{2}$ to destroy the uranium-containing organic compounds), after which, we added ferric chloride solution at the rate of $50 \mathrm{mg}$ of iron/L water sample and precipitated the hydroxides with ammonia $(\mathrm{pH}=8)$. The precipitate was allowed to settle for 1-2 hours, and the clear solution above the sediment was decanted. Next, the precipitate was filtered through a 'white ribbon' filter with a diameter of $11 \mathrm{~cm}$. The precipitate on the filter was dissolved in $50 \mathrm{~mL}$ hot $7 \mathrm{M}$ boiling $\mathrm{HNO}_{3}$, added in small portions, so as to obtain all the solids. Then, the filter was washed two times with $10 \mathrm{~mL}$ hot $\mathrm{HNO}_{3}$.

\section{Extraction of uranium isotopes}

The obtained $\mathrm{HNO}_{3}$ solution containing the uranium isotopes was transferred to a separating funnel, $15 \mathrm{~mL}$ of freshly purified $30 \%$ tributylphosphate (TBP) in toluene was added and extraction was carried for 5 minutes. The mother liquor was poured back into the beaker after phase separation; the organic extract was washed twice with an equal volume of $7 \mathrm{M}$ $\mathrm{HNO}_{3}$ and once with an equal volume of $0.25 \mathrm{M}$ $\mathrm{HNO}_{3}$ solution in $0.04 \mathrm{M} \mathrm{HF}$ for 1 minute. Then, the re-extraction of uranium was carried out. The organic phase was washed three times, each for 1 minute, with portions of $15 \mathrm{~mL}$ distilled water. The combined aqueous re-extracted solution was evaporated to dryness; $5 \mathrm{~mL}$ of concentrated $\mathrm{HNO}_{3}$ was added to remove traces of organic substances and again evaporated to dryness.

\section{Electrolytic precipitation of uranium isotopes}

The dry residue containing the isotopes of uranium was dissolved in $10 \mathrm{~mL}$ of $2 \%$ soda solu- tion with heating, filtered through a 'blue band' filter and put into the electrolytic cell. Electro-deposition of uranium isotopes was conducted on a stainless steel substrate for $30 \mathrm{~min}$ utes at a constant current of $2 \mathrm{~A}$. The sample for counting was tested using the alpha-type spectrometer Alpha Analyst (Canberra, USA). Because modern alpha spectrometers, such as Alpha Analyst (CANBERRA) and Progress-Alpha (Russia), with passivated implanted planar silicon (PIPS) detectors are characterised by very low and stable radiation background (single impulses in 1 hour set for analytical parts of the spectrum), in most cases, the sample count rate measurements are much greater than the background radiation count rate $\left(10^{2}-10^{3}\right.$ or more times).

According to the requirement of Sanitary Regulations and Standards (SanR\&S, p.5.3.5) 0193-06, when there are natural and artificial radionuclides in drinking water, creating an effective dose of $<0.2 \mathrm{mSv} /$ year, it is not necessary to carry out any action to decrease the radioactivity. This dose of $2 \mathrm{~kg} /$ day consumed in water corresponds to the average values of specific activity for the year (intervention levels [ILs] in becquerel [Bq] per kilogram): ${ }^{238} \mathrm{U}-6.2$; ${ }^{235} \mathrm{U}-6.0 ;{ }^{234} \mathrm{U}-5.8 ;{ }^{230} \mathrm{Th}-1.32 ;{ }^{226} \mathrm{Ra}-1.0$; ${ }^{222} \mathrm{Rn}-60 ;{ }^{210} \mathrm{Bi}-220 ;{ }^{210} \mathrm{Po}-0.24 ;{ }^{210} \mathrm{~Pb}-0.4$ etc.).

If several radionuclides are jointly present in water, they must satisfy the following condition:

$$
\sum_{i=1}^{n} \frac{A_{i}}{y B_{\mathrm{i}}} \leq 1
$$

where $A_{i}$ is the specific activity of i-radionuclide in water; and $y B_{i}$ is the appropriate IL of the isotope.

\section{Results and discussion}

The analysed water samples were taken from various reservoirs in the Samarkand, Navoi and Bukhara regions. The analysis of five selected samples (Table 1) shows that the total alphabeta activity is at the level of the limit values established in the Republic of Uzbekistan for drinking water. Among the samples, a relatively 
Table 1 Results of volumetric activity of natural radionuclides and total alpha-beta activity of water taken from different reservoirs

\begin{tabular}{ccccccc}
\multirow{2}{*}{$\begin{array}{c}\text { Number of the } \\
\text { sample }\end{array}$} & \multicolumn{9}{c}{ Volumetric activity (Bq/L) } & \multicolumn{2}{c}{ The total volumetric activity (Bq/L) } \\
\cline { 2 - 7 } & U -238 & Ra-226 & Th-232 & Po-210 & Alpha radiation & Beta radiation \\
\hline 1 & 0.76 & 0.016 & 0.18 & 0.013 & $0.17 \pm 0.07$ & $0.60 \pm 0.30$ \\
\hline 2 & 0.81 & 0.019 & 0.26 & 0.016 & $0.18 \pm 0.09$ & $0.41 \pm 0.40$ \\
\hline \multicolumn{7}{c}{ Underground water } \\
\hline 3 & 0.58 & 0.032 & 0.37 & 0.052 & $0.23 \pm 0.10$ & $0.22 \pm 0.16$ \\
\hline 4 & 0.91 & 0.024 & 0.22 & 0.010 & $0.24 \pm 0.08$ & $0.51 \pm 0.17$ \\
\hline 5 & 0.98 & 0.014 & 0.18 & 0.008 & $0.36 \pm 0.09$ & $0.50 \pm 0.38$ \\
\hline
\end{tabular}

Table 2 Results of determination of the isotopic composition of uranium in different reservoirs

\begin{tabular}{|c|c|c|c|}
\hline \multirow{2}{*}{ Number of the sample } & \multirow{2}{*}{ The number of impulses, ${ }^{234} U /{ }^{238} U$} & \multicolumn{2}{|c|}{ Concentration of ${ }^{234} U(\mu \mathrm{g} / \mathrm{g})$} \\
\hline & & In parallel samples & Average \\
\hline \multirow{2}{*}{1} & $16500 / 13200$ & $66.76 \pm 1.2$ & \multirow{2}{*}{$66.11 \pm 1.3$} \\
\hline & $12400 / 10200$ & $65.45 \pm 1.4$ & \\
\hline \multirow{2}{*}{2} & $13900 / 10600$ & $70.03 \pm 1.4$ & \multirow{2}{*}{$70.14 \pm 1.3$} \\
\hline & $14600 / 11100$ & $70.25 \pm 1.2$ & \\
\hline \multirow{2}{*}{3} & $15300 / 10600$ & $77.10 \pm 1.2$ & \multirow{2}{*}{$77.75 \pm 1.2$} \\
\hline & $18200 / 12400$ & $78.39 \pm 1.1$ & \\
\hline \multirow{2}{*}{4} & $18900 / 10600$ & $95.23 \pm 1.2$ & \multirow{2}{*}{$94.41 \pm 1.1$} \\
\hline & $21200 / 12100$ & $93.58 \pm 1.0$ & \\
\hline \multirow{2}{*}{5} & $23900 / 11200$ & $113.97 \pm 1.0$ & \multirow{2}{*}{$114.89 \pm 1.0$} \\
\hline & $21900 / 10100$ & $115.81 \pm 1.0$ & \\
\hline
\end{tabular}

high content of total alpha activity was detected in samples 3 , and 5 .

From the results shown in Table 1, it is seen that the volumetric activities of natural radionuclides do not exceed the normal ILs.

The results of the analyses of the isotopic composition of uranium in natural waters, taken from various reservoirs, by alpha-spectrometry (Table 2) showed that there is a breach of the radioactive equilibrium between the isotopes of uranium $\left({ }^{234} \mathrm{U} /{ }^{238} \mathrm{U}\right)$. That is, the greater the concentration of ${ }^{234} \mathrm{U}$ isotope in water samples, the higher is the total volumetric alpha activity. At radioactive equilibrium of uranium isotopes, the concentration of ${ }^{234} \mathrm{U}$ must be at the level of $53.41 \pm 1.5 \mu \mathrm{g} / \mathrm{g}$ (radioactive equilibrium factor).
The results in Table 2 confirm that our assumptions are correct, and that there is a connection between the total alpha activity and the concentration of ${ }^{234} \mathrm{U}$ isotope.

From these results, it is seen that in groundwater, the ${ }^{234} \mathrm{U}$ isotope concentration is greater than in the surface waters. In our case, Sample 1 and Sample 2 are surface waters, and the Samples 3, 4 and 5 are underground waters.

During the selection of water samples, the $\mathrm{pH}$ of each sample was determined. After receiving the ${ }^{234} \mathrm{U}$ isotope concentration values, the dependence (Figure 1) of this value on the $\mathrm{pH}$ was plotted in a graph.

As shown in Figure 1, in a weak acidic medium, when the pH changes from 4.0 to 6.8 , the concentration of the ${ }^{234} \mathrm{U}$ isotope in groundwa- 


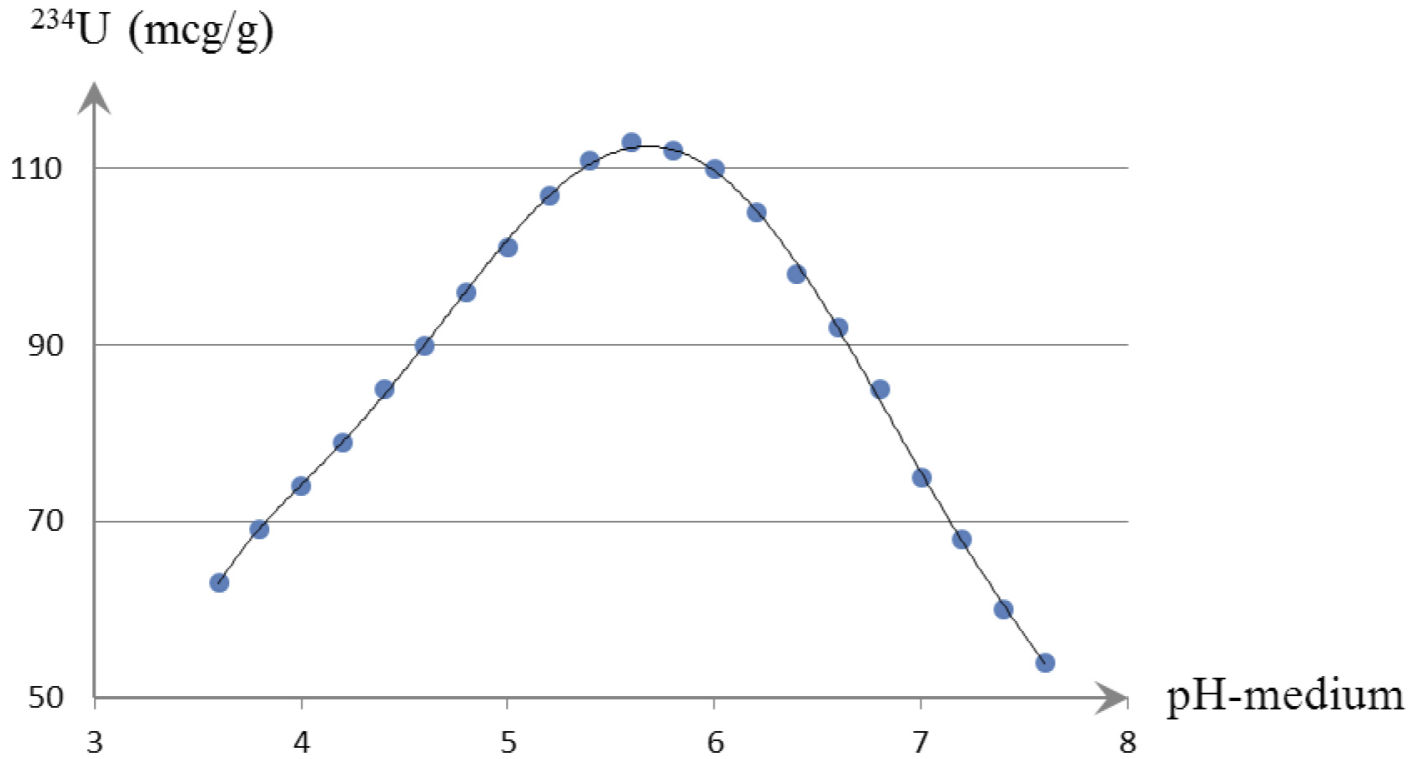

Figure 1 Dependence of the concentration of ${ }^{234} \mathrm{U}$ isotope on the $\mathrm{pH}$ of the medium.

Table 3 Results of dependence of concentration of isotope ${ }^{234} \mathrm{U}$ on the $\mathrm{pH}$ of the medium

\begin{tabular}{|c|c|c|}
\hline Sample no. & $\begin{array}{c}\text { pH of } \\
\text { medium }\end{array}$ & $\begin{array}{c}\text { Concentration } \\
\text { of }{ }^{234} \mathbf{U}\end{array}$ \\
\hline 1 & 3.6 & 63 \\
\hline 2 & 3.8 & 69 \\
\hline 3 & 4 & 74 \\
\hline 4 & 4.2 & 79 \\
\hline 5 & 4.4 & 85 \\
\hline 6 & 4.6 & 90 \\
\hline 7 & 4.8 & 96 \\
\hline 8 & 5 & 101 \\
\hline 9 & 5.2 & 107 \\
\hline 10 & 5.4 & 111 \\
\hline 11 & 5.6 & 113 \\
\hline 12 & 5.8 & 112 \\
\hline 13 & 6 & 110 \\
\hline 14 & 6.2 & 105 \\
\hline 15 & 6.4 & 98 \\
\hline 16 & 6.6 & 92 \\
\hline 17 & 6.8 & 85 \\
\hline 18 & 7 & 75 \\
\hline 19 & 7.2 & 68 \\
\hline 20 & 7.4 & 60 \\
\hline 21 & 7.6 & 54 \\
\hline
\end{tabular}

ter increases sharply to $120 \mu \mathrm{g} / \mathrm{g}$ in our cases (instead of the equilibrium concentration: $53.41 \mu \mathrm{g} / \mathrm{g}$ ). When the medium becomes neutral, i.e., at $\mathrm{pH}=7.0$, the ${ }^{234} \mathrm{U}$ isotope concentra- tion in groundwater is reduced to the equilibrium concentration of $53.41 \mu \mathrm{g} / \mathrm{g}$.

As we know, in natural conditions, natural radioisotopes pass from the rocks into water, usually due to mineral dissolution and leaching. However, in natural waters, because of the difference in the migration abilities of radioactive elements and their isotopes, there is a violation of the radioactive equilibrium in the uranium series, and therefore the ratio between the different isotopes of the same element may differ from the equilibrium tens and hundreds of times. The main reason for the breach of radioactive equilibrium in neutral aqueous phase is that the uranium in natural conditions exists in the four $\left(\mathrm{U}^{4+}\right)$ and six $\left(\mathrm{U}^{6+}\right)$ (in the form of uranyl ion $\mathrm{UO}_{2}{ }^{+2}$ ) valence states; however, only the four valence state ions $\left(\mathrm{U}^{4+}\right)$ are stable in neutral medium. This causes the differential solubility of uranium compounds in water (e.g., solubility in neutral water $\mathrm{U}(\mathrm{OH})^{4-} \sim 10-12 \mathrm{~mol} / \mathrm{L}$ $\left.\mathrm{UO}_{2}(\mathrm{OH})^{2-} \sim 10-9 \mathrm{~mol} / \mathrm{L}\right)$, which leads to the predominance of the tetravalent uranium over the hexavalent ion.

Based on the research results, the following conclusions can be made.

Comparison of the total specific alpha-beta activity of the samples of natural waters of various reservoirs with the rated value of drinking water shows that in all cases, the total specific 
alpha-beta activity complies with the prescriptions for drinking water quality established in the Republic of Uzbekistan.

Determining the isotopic composition of natural radionuclides is absolutely necessary not only to confirm the correctness of the analysis but also to solve the problem of occurrence of the source of a particular radioisotope in a particular natural object.

Thus, the execution of the background radiation monitoring tasks is a necessary step for determining the source of contamination. Therefore, the use of alpha-spectrometric method of determination of natural uranium isotopes allows us to solve the problem of background radiation monitoring in natural waters and provides a basis for the development of measures to identify the source of contamination in natural environmental objects.

\section{References}

[1] Vozzhenikov, G.S., Belyshev, Y. (2006): Radiometry and nuclear geophysics. Tutorial, Yekaterinburg, $418 \mathrm{p}$.

[2] Bakhur, A.E. (1996/97): The radioactivity of natural waters. ANRY №2 (8), pp. 32-39.
[3] Bakhur, A.E., Malyshev, V.I., Manuilova, L.I. et al. (1997): Radioactivity of Natural waters: From theory to practice. ANRY №4 (10), pp. 54-59.

[4] Bakhur, A.E, Martynyuk, Y.N., Tutelian, O.E. (2000): Some principles of radiation monitoring of drinking water systems. Public health and environment. News bulletin. Ministry of Health of the Federation of Russia, FC GSEN, №3 (84), pp. 13-15.

[5] Muzafarov, A.M., Sattarov, G., Dumbrava, A.A., Petukhov, O.F., Oslopovsky, S.A. (2005): Investigation of the isotopic composition of uranium alpha-spectrometry. Mining Bulletin of Uzbekistan, 22, pp. 94-98.

[6] Muzafarov, A.M., Sattarov, G.S., Glotov, G.N., Kist, A.A. (2011): On the issue of violation of the balance between the coefficient of radioactive uranium isotopes. Mining Bulletin of Uzbekistan, 29, pp. 137-139.

[7] Muzafarov, A.M., Sattarov, G.S., Kutbeddinov, A.K., Allaberganova, G.M. (2011): Methods for the preliminary assessment of radioactivity of natural waters. Innovative technologies of mining and metallurgical industry. Theses of reports of Res. con. Navoi, October 21, 2011, pp. 207-208.

[8] Sanitary Regulations and Standards of radiation safety. SanPiN № 0193-06, (NRB and OSPORB -2006). Tashkent, $86 \mathrm{p}$. 